\title{
THE MEMBRANE ACTIVE ANTIBIOTICS EFFECTS ON RAT HEART MYOCARDIUM
}

\author{
GOPČEVIĆ KRISTINA*, GOJGIĆ-CVIJOVIĆ GORDANA**, PAVLOVIĆ MIRJANA*, \\ MILIĆEVIĆ ŽIVANA* and STEVANOVIĆ D* \\ *School of Medicine, Belgrade \\ **Institute of Chemistry, Technology and Metallurgy, Belgrade
}

(Received 6. September 2005)

The effect of some membrane active ionophoric antibiotics on the amplitude of contractions of isolated rat heart right ventricle was studied. The effects of polyether nigericin, polyene amphotericin $B$ and peptide antibiotic polymyxin $B$ were examined. Nigericin in a concentration of $1.38 \mu \mathrm{mol} / \mathrm{L}$ exerts a positive inotropic effect with its maximal value $(+29 \%) 15$ minutes after application. Amphotericin B in a concentration of $1.08 \mu \mathrm{mol} / \mathrm{L}$ caused a positive inotropic effect, which was maximal in the $30^{\text {th }}$ minute of the experiment $(+28 \%)$. Polymyxin $B$ in a concentration of $0.84 \mu \mathrm{mol} / \mathrm{L}$ caused a positive inotropic effect, which was maximal (+32\%) 20 minutes after application.

Key words: ionophores, myocardium, inotropic

\section{INTRODUCTION}

The ionophores are defined as compounds which form lipid soluble, dynamically reversible cation complexes which act as vehicles for transporting ions across biological membranes and changed transmembrane electric potential (Moore et al., 1964). Antibiotics which express ionophoric effects are of different chemical structures: polyene, polyether, polypeptide.

Most of the polyether antibiotics were isolated from fermentation broth of different species of Streptomyces genus. It is known that polyether antibiotics contain the carboxylic group which bonds cations with specific selectivity (for example, nigericin selectivity is as follows: $\left.\mathrm{K}^{+}>\mathrm{Rb}^{+}>\mathrm{Na}^{+}>\mathrm{Cs}^{+}>\mathrm{Li}^{+}\right)$. Some authors supposed that the possible mechanism for antimicrobial activity of nigericin was based on decreasing $\mathrm{K}^{+}$content and $\mathrm{pH}$ value in the cytoplasm (Painter G. and Pressman B.C., 1985). Because of these antimicrobial effects, polyether antibiotics were used as coccidiostatics in veterinary medicine (monensin) and as food additives (monensin, lasalocid) (Lanzini G. and Lorenzeti R., 1993).

Polypeptide antibiotics act as surface active compounds. They bind to the cell membrane and cause the membrane potential to decrease. Possible interactions of polypeptide antibiotics with membrane constituents were investigated in the interaction of polymyxin with liposomes (Pressman B.C. and de 
Guzman N.T., 1975). The polymixins are a group of polypeptide antibiotics, with a molecular mass of approximately $100 \mathrm{kD}$, isolated from different strains of Bacillus. These antimicrobial agents are characterized by a heptapeptide ring, a high content of diaminobutyric acid and a side chain ending in fatty acid residues. Polymyxin B is currently used against Gram negative bacteria. All of the polymyxins are cationic detergents that disrupt the biofilm which results in altered membrane permeability. The effect of polymyxin $B$ is identical to the effects of EDTA. The target, like that of EDTA, is most likely the biofilm, via displacement of magnesium and calcium ions. This effect could be reversed by an excess of these divalent cations. (Straton C.W., 1996, Pressman C.B. and Fahim M. 1982).

Polyene antibiotics contain at least 4-7 double bonds, a lactone ring $\mathrm{C}_{12}-\mathrm{C}_{38}$ and the sugar component mycosamine. They increase cell membrane permeability by forming complexes with sterols, which causes loss of intracellular low molecular weight components. Amphotericin B and nystatin are used in medicine for systematic treatment of mycosis (Lanzeti and Lorenzeti, 1993.)

Physiological effects of polymyxins have been ascribed to the calciummobilizing effects in platelet coagulation, release of histamine from mast cells, fertilization of eggs and a variety of calcium-mediated exocytotic processes (Pressman and de Guzman, 1975, Pressman and Fahim, 1982).

It was proved that monovalent ionophores and digitalis, which directly inhibits the activity of $\mathrm{Na} / \mathrm{K}-\mathrm{ATP}$-ase, exert synergistic effects on $\mathrm{Ca}^{2+}$ transport into the cell, displace intracellular sequestered $\mathrm{Ca}^{2+}$ and release biogenic amines (Bourguignon and Pressman, 1983; Painter and Pressman, 1985).

The discovery that monovalent ionophores and digitalis exert synergistic effects on cellular processes, suggests that there are biological control mechanisms by which $\mathrm{Na}^{+}$modulates the availability of $\mathrm{Ca}^{2+}$ to intracellular receptors and start cellular activities (Liu and Hermani, 1978; Painter and Pressman, 1985).

Considering the effects of $\mathrm{Ca}^{2+}$ and catecholamines on the cardiovascular system, the ionophoric antibiotics may evoke different cardiovascular effects (Painter, Pressman, 1985). Ion membrane transport is important for the mechanism of myocardial contractility, hence we decided to examine the inotropic effects of ionophoric antibiotic polyether nigericin, polyene amphotericin $B$ and peptide polymyxin $B$, in in vitro conditions.

\section{MATERIAL AND METHODS}

The effect of ionophoric antibiotics on the isolated right ventricle of rat heart was investigated. Polyether antibiotic nigericin (Sigma, USA), polyene antibiotic amphotericin B (Sigma, USA) and peptide antibiotic polymyxin B (Sigma, USA) were studied.

Wistar rats weighting 190-210 g were used in this experiment. Experimental animals were divided into three experimental groups of seven animals each. After sacrificing the rats the heart was rapidly removed and the right ventricle was dissected. Each ventricle was put on the boot electrode which was than placed in a bath of Tyrode's solution of the following composition (in $\mathrm{mmol} / \mathrm{L}$ ): $\mathrm{NaCl} 136.9$; 
Acta Veterinaria (Beograd), Vol. 56. No. 2-3, 149-156, 2006.

Gopčević Kristina et al.: The membrane active

antibiotics effects on rat heart myocardium

$\mathrm{KCl}$ 2.69; $\mathrm{CaCl}_{2}$ 1.8; $\mathrm{MgCl}_{2}$ 1.05; $\mathrm{NaHCO}_{3}$ 11.9; $\mathrm{NaH}_{2} \mathrm{PO}_{4} 0.42$ and glucose 5.55, bubbled with $95 \% \mathrm{O}_{2} / 5 \% \mathrm{CO}_{2}$. The volume of the bath was $25 \mathrm{~mL}, \mathrm{pH} 7.4$ and its temperature kept at $37^{\circ} \mathrm{C}$. Contractions were induced with square wave impulses of twice the diastolic thresholds and duration of $5 \mathrm{~ms}$ at a frequency of $1 \mathrm{~Hz}$. The contractions were recorded via an isometric transducer (sensitivity of $0.05 \mathrm{~g} / \mathrm{cm}$ ) into a micro dynamometer (7050, Ugo Basile). The preparation was stabilized for 30 minutes and after that the investigated ionophoric antibiotics were added to the bath and contractions were recorded for further 30 minutes.

In the first experimental group, the right heart ventricle was treated with $1.38 \mu \mathrm{mol} / \mathrm{L}$ of nigericin, the second group with $1.08 \mu \mathrm{mol} / \mathrm{L}$ of amphotericin $\mathrm{B}$, and the third group with $0.84 \mu \mathrm{mol} / \mathrm{L}$ of polymyxin B.

For histological analysis of the heart specimens, after 30 minutes of action of the tested substances, the right ventricles were taken from the bath and immersed into neutral formaldehyde solution (10\%), placed in paraffin and cut in $4 \mathrm{~mm}$ slices. Specimens were treated with haematoxylin-eosin dye according to acidopikro Mallory's method (Bancroft and Stevens, 1982).

As a control a group of 7 animals whose ventricles were subject to the identical experimental procedure, but without the addition of investigated substances was used. In these preparations the amplitude of contractions did not change through out the experiment (60 min.)

Results are presented (see figures) as percentage change from the starting point. Statistical analysis was performed by paired Student's t-test. The means \pm SEM of $n$ observations are quoted in the text and figures, and $p<0.05$ was considered statistically significant.

\section{RESULTS}

Nigericin in a bath concentration of $1.38 \mu \mathrm{mol} / \mathrm{L}$ produces a positive inotropic effect on the amplitude of contractions (Fig. 1).

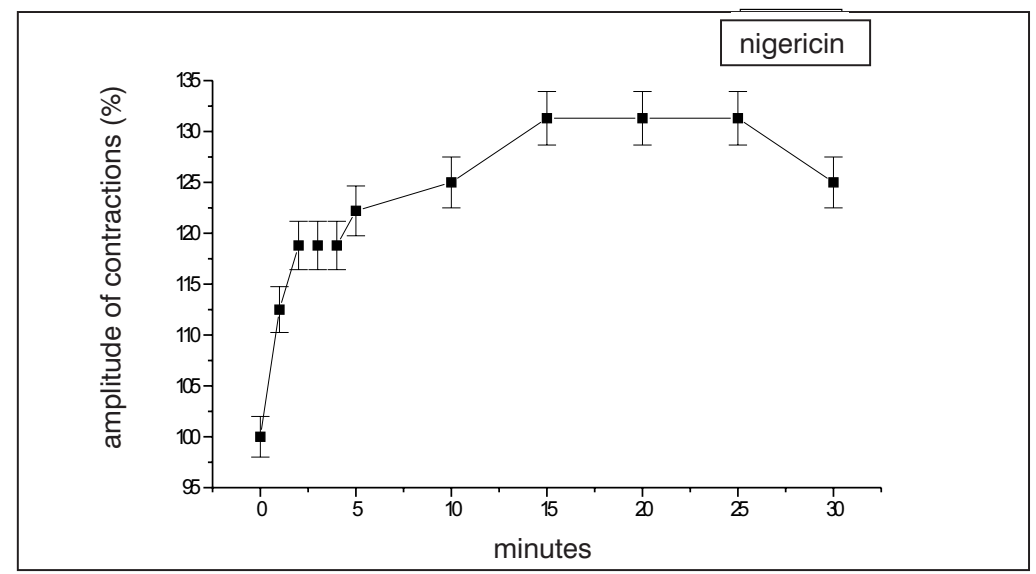

Figure 1. The inotropic effect of nigericin on the amplitude of contractions of isolated right ventricle of rat heart. Concentration of nigericin $-1.38 \mu \mathrm{mol} / \mathrm{L}$. Control (amplitude of contraction of isolated right ventricle without nigericin), represents $100 \%$ value 
In the first minute, the amplitude of contractions increased by $15 \%(p<0.05)$ when compared to the control value. In a short period of nigericin action, between the $2^{\text {nd }}$ and $4^{\text {th }}$ minute, there was no change in the amplitude. From the $4^{\text {th }}$ minute, nigericin showed a positive inotropic effect which reached its maximum in the $15^{\text {th }}$ minute $(+29 \%, p<0.05)$. In the period from the $15^{\text {th }}$ and $25^{\text {th }}$ minute there was no change in the contractions amplitude. By the end of the experimental treatment (30 minutes) there was a slight decrease of the amplitude of contractions.

Amphotericin $B$ in a concentration of $1.08 \mu \mathrm{mol} / \mathrm{L}$ produced a positive inotropic effect on isolated right ventricle of rat heart (Fig. 2).

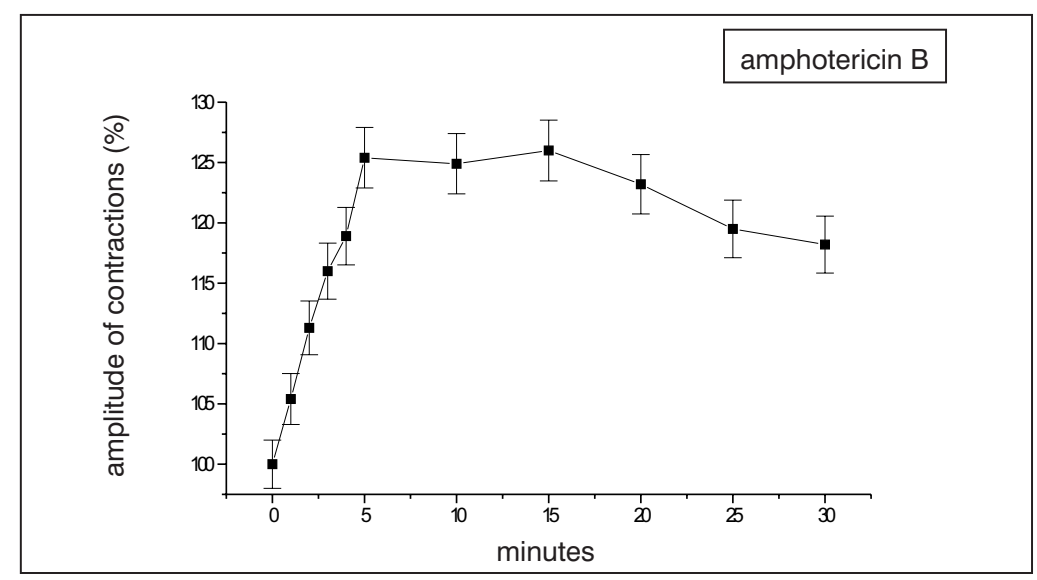

Figure 2. The inotropic effect of amphotericin B on the amplitude of contractions of isolated right ventricle of rat heart. Concentration of amphotericin $B-1.08 \mu \mathrm{mol} / \mathrm{L}$. Control (amplitude of contraction of isolated right ventricle without amphotericin B), represents $100 \%$ value

This effect was evident immediately after its addition to the bath, and reached its maximum at the $5^{\text {th }}$ minute of action. At this time the amplitude of contraction was $28 \%(p<0.05)$ higher then in the control group. In the period from the $5^{\text {th }}$ to $15^{\text {th }}$ minute the amplitude of contractions kept its maximal value, after which slightly decreased. In the $30^{\text {th }}$ minute the amplitude of contractions was $14 \%$ over the control $(p<0.05)$.

Polymyxin B in the applied concentration of $0.84 \mu \mathrm{mol} / \mathrm{L}$ caused a positive inotropic effect on isolated right ventricle. This effect was evident immediately after addition to the bath (Fig. 3).

The effect of polymyxin B was more pronounced in the period from the $5^{\text {th }}$ and $10^{\text {th }}$ minute. Maximal positive inotropic effect was attained at the $20^{\text {th }}$ minute. At that time the amplitude of contractions was $32 \%(p<0.05)$ higher, compared to the control. During the period from the $20^{\text {th }}$ to $25^{\text {th }}$ minute, the amplitude of the contractions was slightly reduced, and in the $30^{\text {th }}$ minute increased $24 \%$, compared to the control. 
Acta Veterinaria (Beograd), Vol. 56. No. 2-3, 149-156, 2006.

Gopčević Kristina et al.: The membrane active

antibiotics effects on rat heart myocardium

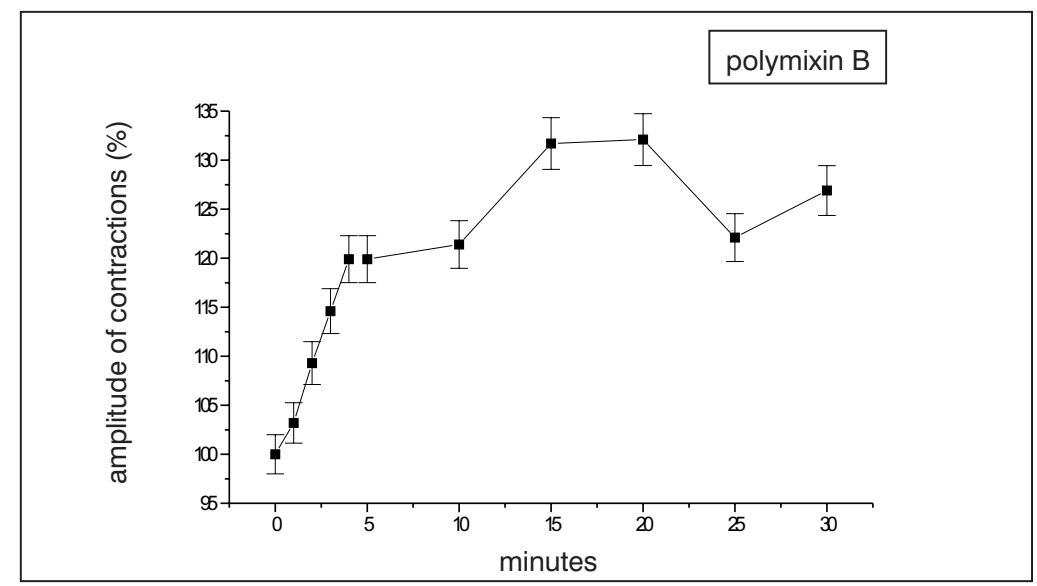

Figure 3. The inotropic effect of polymyxin B on the amplitude of contractions of isolated right ventricle of rat heart. Concentration of polymyxin $B-0.84 \mu \mathrm{mol} / \mathrm{L}$. Control (amplitude of contraction of isolated right ventricle without polymyxin B), represents $100 \%$ value

Typical microphotography of isolated right ventricle of rat heart, during the action of membrane active antibiotics, is presented in Fig. 4.

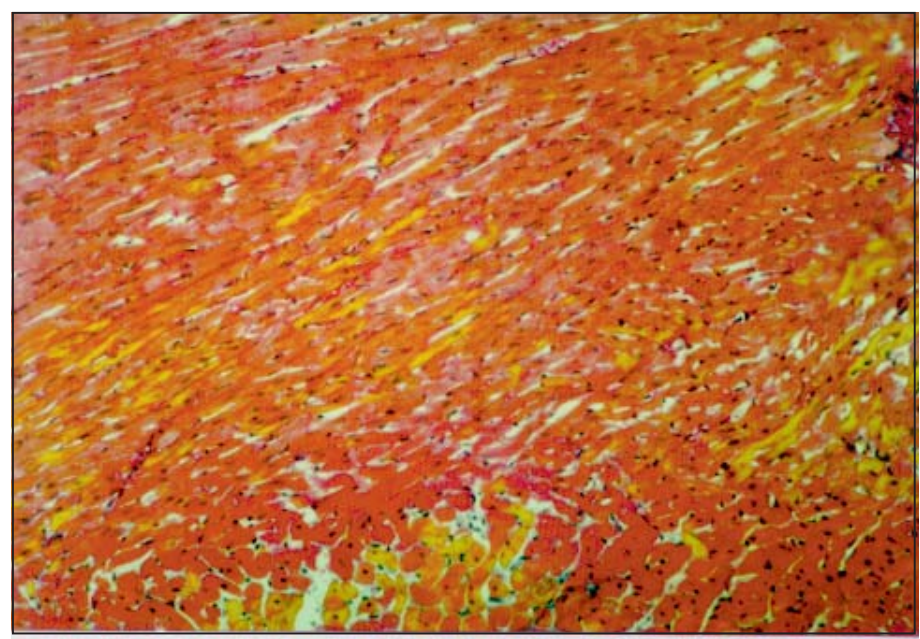

Figure 4. Microphotography of isolated right ventricle of rat heart, after the action of amphotericin B. Hematoxylin eosin, X 125 
Slight morphological changes, such as vasodilatation were observed. There are numerous venulae in the outer layer and numerous capillaries, which implies hyperaemia, but without necrotic changes.

\section{DISCUSSION}

The obtained results showed that all applied antibiotics cause a positive inotropic effect on the isolated right ventricle of the rat heart. This effect was more pronounced $(+32 \%)$ during polymyxin B action, in a concentration of $0.84 \mu \mathrm{mol} / \mathrm{L}$, compared to the control value. Amphotericin B in a concentration $1.08 \mu \mathrm{mol} / \mathrm{L}$ caused a slightly reduced positive inotropic effect $(+28 \%)$. A similar positive inotropic effect $(+29 \%)$ was obtained during the action of $1.38 \mu \mathrm{mol} / \mathrm{L}$ of nigericin.

The investigations of the effects of ionophoric antibiotics showed that they complexed and transported calcium through biological membranes (Pressman and Fahim, 1982). It is known that ionophores are highly lipophilic substances, their hydrophobic layer is immersed into the membrane, while its hydrophilic part can bind some cations (Painter and Pressman, 1985). Because of those characteristics, ionophores serve as cation transporters through biological membranes. Ion transport ability via carboxylic ionophores was a result of lipophilic, dipolar, cationic inclusion and complex formation. It was shown that oxazolomycin (produced by Streptomyces albus) effectively transports protons and monovalent cations $\left(\mathrm{K}^{+}\right)$at $\mathrm{pH}<7$. This activity is in correlation with its antibacterial, antiviral and cytotoxic activity. This role of ionophoric antibiotics, especially those isolated from genus Streptomyces, could have a practical application, as well (Sverdlova et al., 1997). Ionophoric properties of fusafungin have a role in its antibiotic action when applied as a local therapeutic (Levy, 1995). Antibiotics magainins are natural cytolytic agents and could be used in the therapy of certain tumors.

It was shown that ionophores in low concentrations liberated calcium ions bonded to the inner membrane; while at high concentrations they induce simultaneous inlet and outlet of calcium through the inner mitochondrial membrane (Pressman and Fahim, 1982). Having in mind that the rise in cytosolic $\mathrm{Ca}^{2+}$ exerts cellular activation such as in muscle contraction, secretion, exocytosis and synaptic transmission (Moore and Pressman, 1964; Painter and Pressman, 1985), we may suppose that the findings obtained in our experiments were the consequence of the increase of the sarcoplasmatic $\mathrm{Ca}^{2+}$ in the myocardial cells. Also, many other authors in in vivo experiments on dogs, have shown that ionophores express different haemodynamic effects: decrease of diastolic pressure in aorta and systolic pressure in the left ventricle and increased coronary flow.

Positive inotropic effects, obtained in our experiments on isolated right ventricle of rat heart, during the action of applied antibiotics are in agreement with the published data. It was shown that ionophores caused positive inotropic and chronotropic effects (Massini and Luscher, 1974). Stimulation of cardiovascular function using ionophores could be applied in chronic changes of the heart, such as shock, ischemia or coronary insufficiency (Sato and Tsuchida, 1999). 


\section{CONCLUSION}

Amphotericin B, nigericin and polymyxin B show a positive inotropic effect on the isolated right ventricle of rat heart. Having in mind the lower toxicity of ionophoric antibiotics compared to the glycoside substances used as cardiotonics in pharmacotherapy and the high selectivity of ionophores for some cations, the obtained results imply the possible use of those substances in improving the function of insufficient myocardium.

\section{ACKNOWLEDGEMENT:}

The authors thank to Mirjana Mraović, grad. chem. for having kindly purchased the amphotericin $B$ and polymixin $\mathrm{B}$, used in this work.

Address for correspondence:

Kristina Gopčević, Institute for chemistry,

School of Medicine, Višegradska 26,

11000 Belgrade, Serbia\&Montenegro

e-mail:kgopcevic@yahoo.com

\section{REFERENCES}

1. Bancroft JD, Stevens A, 1982. Theory and Practice of Histological Techniques, Second edition, Churchill Livingstone Edinbourgh, London, Melbourne and New York, 114-6.

2. Bourguignon LYW, Pressman BC, 1983, Stimulation of lymphocyte receptor capping by the ionophore monensin, J Memb Biol, 43, 91-3.

3. Lanzini G, Lorenzeti R, 1993, Biotechnology of Antibiotics and Other Bioactive Microbial Metabolities. Plenum Press, New York and London, 35-49.

4. Levy D, Bluzat A, Seigneuret M, Rigaud JL, 1995, Alkali cation transport through liposomes by the antimicrobial fusafungine and its constitutive enniatins, Biochem Pharmacol, 50, 2, 2105-7.

5. Liu CH, Hermani TE, 1978, Characterization of ionomycin as a calcium ionophore, $\mathrm{J}$ Biol Chem , 253, 5892-4.

6. Massini P, Luscher EF, 1974, Some effect of ionophores for divalent cations on blood platelets: Comparison with the effect of thrombin, Biochem Biophys Acta, 372, 109-17.

7. Moore C, Pressman BC, 1964, Mechanism of action of valinomycin on mitochondria, Biochem Biophys Res Commun, 15, 562-7.

8. Painter G, Pressman BC, 1985, Cation Complexes of the monovalent and Polyvalent Carboxylic Ionophores: Lasalocid (X-537A), Monensin, A23187 (Calcimycin), and related antibiotics. In: Metal ions in Biological systems, Ed. Helmut Sigel, Vol 19, Antibiotics and their complexes, Marcel Dekker, Inc., New York and Basel, 229-94.

9. Pressman BC, de Guzman NT, 1975, Biological application of ionophores: Theory and practice, Ann NY Acad Sci USA, 264, 373-86.

10. Pressman CB, Fahim M, 1982, Pharmacology and toxicology of the monovalent carboxylic ionophores, Ann Rev Pharmacol, 22, 465-90.

11. Sato H. and Tsuchida K., 1999. Pharmacological actions of monovalent ionophores on spontaneously beating rabbit sino-atrial nodal cells. Gen.Pharmacol. 33, 2, 151-9.

12. Straton CW, 1996, Mechanisms of Action for Antimicrobial Agent: General Principles and Mechanisms for Selected classes of Antibiotics. In: Antibiotics in Laboratory Medicine, Victor Loraine Ed., $4^{\text {th }}$ Ed., Williams and Wilkins, New York.

13. Sverdlova AN, Lihkacheva AA, Lozitskaia ND, Nefelova MV, 1997, Antibiotic and electrochemical properties of some natural ionophoric compounds from streptomycetes, Mol Gen Mikrobiol Virusol, 2, 29-33. 


\section{EFEKTI ANTIBIOTIKA KOJI DELUJU NA ĆELIJSKE MEMBRANE NA SRCE PACOVA}

KRISTINA GOPČEVIĆ, GORDANA GOJGIĆ-CVIJOVIĆ, MIRJANA PAVLOVIĆ, ŽIVANA MILIĆEVIĆ i STEVANOVIĆ D

\section{SADRŽAJ}

Amfotericin B, nigericin i polimiksin B pokazuju pozitivni inotropni efekat na izolovanu desnu komoru srca pacova. Imajući u vidu nižu toksičnost jonofornih antibiotika u poređenju sa glikozidnim supstancama koje se u farmakoterapiji koriste kao kardiotonici i visoku selektivnost jonofora prema nekim katjonima, dobijeni rezultati ukazuju na moguću upotrebu ovih supstanci u poboljšanju funkcije insuficijentnog miokarda. 